\title{
용 ODGOVORNOST PRIPADNIKA VOJSKE OD DUŠANOVOG ZAKONIKA DO ZAKONA O VOJNIČKOJ DISCIPLINI
}

Milojko S. Milovanović

dgovornost je univerzalna, složena društvena pojava, temeljni princip i osnovna vrednost na kojoj počiva organizovano ljudsko društvo. Ideal apsolutne odgovornosti predstavlja izazov čijem ostvarenju se teži jer do sada nije ostvaren u apsolutnom smislu. Sastavni deo ukupne odgovornosti u društvu je i odgovornost pripadnika vojske koja je specifična iz razloga što je uslovljena namenom organizovane oružane sile. Za pripadnika vojske je propisan standard ponašanja koji podrazumeva da se naređenja, odluke ili nalozi pretpostavljenih starešina izvršavaju bez pogovora, potpuno, tačno i na vreme izuzev slučaju kada bi njihovo izvršenje predstavljalo krivično delo. Odstupanje od navedenog standarda za posledicu ima odgovornost onog pripadnika vojske koji svoje postupanje nije uskladio sa zakonom, pravilima, društvenim zahtevima i potrebama. Ta odgovornost je kompleksna i obuhvata više pojavnih oblika, a počeci njihovog uređenja sežu u daleku prošlost. Počev od Dušanovog zakonika, pa do Zakona o vojničkoj disciplini uređeni su osnovi krivične, disciplinske i odgovornosti za narušavanje javnog reda kroz propisivanje pojavnih oblika krivičnih dela i disciplinskih istupa, kazni koje se izriču za njihovo izvršenje, načina na koji se izvršavaju, nadležnost za izricanje, obaveza vršenja službe u skladu sa zakonom, organizacija i nadležnost vojnih sudova, te pravo na žalbu.

Ključne reči: odgovornost pripadnika vojske, krivična odgovornost, krivična dela, kazne i načini izvršenja, disciplinska odgovornost, disciplinske kazne i način izvršenja, vojni sud, žalba

\section{Uvod}

Stvaranje srpske države obeleženo je vekovnim borbama sa zavojevačima. Cen-

Stralnu ulogu u borbi za stvaranje država imala je Vojska. Činjenica je da je Vojska mogla uspešno da funkcioniše samo ako je njena disciplina bila gvozdena, a nesumljive potrebe njenog neprekidnog održavanja „naročito za vreme rata morale su uvek davati povoda postanku vojno-kaznenih propisa, isprva običajno - pravnih, a kasnije

* Dr Milojko S. Milovanović je pukovnik u penziji. 
Iskustva i pouke iz prošlosti

pisanih“. ${ }^{1}$ Stoga je na ovim prostorima tokom istorije stvoren veći broj pisanih izvora koji su se bavili odgovornošću vojnika. Specifičnost ovog perioda se ogleda u činjenici da su u njemu uređeni osnovi pravne odgovornosti kao odgovornosti neodgovornih, a doneti propisi su dokaz da u turbulentnim stanjima društva dominira rigidnost u kažnjavanju gde je kazna određena po vrsti, a visina je u konkretnom slučaju stvar odluke onoga koji o njenoj visini odlučuje. U stabilna vremena se odražavaju tako što se u njima donose propisi koji su studiozniji, sistematičniji, prilagođeni vremenu u kome se donose i predstavljaju odraz realnog sagledavanja pojavnih oblika povreda odgovornosti i propisivanja primerenih kazni.

\section{Dušanov zakonik}

Najstariji propis u staroj srpskoj državi koji se bavi odgovornošću vojnika je Dušanov zakonik donet 1349. godine, a dopunjen 1354. godine. Original zakonika nije sačuvan, a do sada je poznato preko 20 prepisa u različitim redakcijama. O odgovornosti vojnika govore odredbe članova 129 i 131.

Odredbama čl. $129^{2}$ propisano je krivično delo neposlušnosti i ustanovljena nadležnost vojvode za suđenje po svim vojnim krivičnim delima. Naime, tada je vojni sud bio specijalna vrsta državnog suda i vojvode su imale istu vlast kao car. Vladar je „vojni zapovednik i glavni sudija u vojsci. Sada u vezi sa povećanjem države i vojske, on svoju vlast prenosi na vojvode. Pod njihovu nadležnost spadaju vlastela i njihovi ljudi“. ${ }^{3}$

Zakonikom je, u čl. 131, ${ }^{4}$ propisan dvoboj u vojsci i ovim članom se dopušta dvoboj u vojsci jer se, u doba feudalnog uređenja, smatralo da vojnik-vitez treba da bude uvek spreman za megdan koji je u evropskim vojskama bio dopušten do XIX veka. Za pomagače, koji bi se u dvoboj umešali, propisana je smrtna kazna iz razloga što „svađa dvojice vojnika iz dva različita odreda mogla je lako povući za sobom bratstvenike ili zemljake ove dvojice, te je svađa mogla lako da izazove veliki nered u vojsci. Stoga su propisane stroge kazne za te pomagače". 5

Dušanov zakonik je prvi pisani izvor koji, između ostalog, sadrži odredbe o odgovornosti vojnika, te predstavlja kamen temeljac koji je ukazao na značaj navedenog pitanja i poslužio u kasnijem periodu kao uzor za donošenje brojnih propisa.

\footnotetext{
${ }^{1}$ Toma Živanović, Osnovi vojnog krivičnog prava (opšti deo), (Beograd, Grafički Institut „Narodna Misao“, 1924), str. 8.

${ }^{2}$ „Na vojsce, na vsakoj, da obladaju vojvode koliko i car. Što reku da se čuje. Ako li in kto prečuje u čem, da jest tozi osuždenije koje i onemzi koji bi cara preslušali. I sudovi mali i golemi koji su na vojsce, da im sude vojvode, a in nikto“, citat prema: Stojan Novaković, Stara srpska vojska, (Beograd, Kraljevsko - srpska državna štamparija, 1898), str. 61.

${ }^{3}$ Aleksandar V. Solovjev, Zakonik Cara Stefana Dušana 1349. i 1354. godine, (Beograd, SANU, 1980), str. 281.

${ }^{4}$ „Na vojsci svađe da nije, akoli se dva svade, da se biju, a drugi niko od vojnika da im ne pomogne; ako li ko poteče i pomogne izazivaču, oni da se ubiju“, citat prema: Nikola Radojičić, Zakonik Cara Stefana Dušana 1349. i 1354, (Beograd, Naučno delo, 1960), str.125.

${ }^{5}$ Solovjev, Zakonik Cara Stefana Dušana 1349. i 1354. godine, str. 283.
} 


\section{Zakonik Prote Mateje iz 1804. godine}

Nakon dugog vremenskog perioda, u prvom srpskom ustanku, kada u pobunjenim knežinama beogradskog pašaluka „nije bilo nikakve druge vlasti osim vojničke“, 6 javila se potreba, odlaskom ustaničke vojske pod zidine beogradske tvrđave, „narodu sud ostavi$\mathrm{ti}_{,}{ }^{7}$. Formiranje suda neosporno je nametnulo potrebu donošenja zakona na osnovu koga bi se krivcu sudilo i kazna izricala.

Prota Mateja Nenadović je sačinio zakonik koji je usvojen na majskoj skupštine Valjevske nahije 1804. godine koja je održana na Reljinom polju, nedaleko od Brankovine. Zakonik je pisan po uzoru na Kormčiju (zbornik crkvenih zakona), Justinijanove zakone i Mojsijevu strogost nad Jevrejima i njime se pokazuje težnja da se ustanovi krivičko-pravna zabrana određenih ponašanja. Imao je „14, 15 li punktova“, 8 od kojih je Prota Mateja u Memoarima, po sećanju, nabrojao 7 . Za nas su interesantni punkt 4 i punkt $5 .^{9}$

Zakonikom Prote Mateje se prvi put u Srbiji pominje telesna kazna šibanja. Telesne kazne su, u to vreme, praktikovane u mnogim evropskim zemljama (Austrija, Rusija i dr). Pretpostavlja se da je ova kazna najverovatnije uvedena po ugledu na pravo austrijske vojne krajine pre "nego iz turskog ili srednjevekovnog prava koje je predviđalo druge vrste batinanja". ${ }^{10}$ Doneli su je Srbi koji su, na kraju 18 veka, služili u srpsko-austrijskim frajkorima, a njih je najviše bilo u valjevskoj nahiji. Da se radi o novoj krivično-pravnoj sankciji vidljivo je i po tome što su sudovi u svojim odlukama do detalja opisivali način izvršenja izrečene telesne kazne šibanja. U početku je ova kazna predviđena za vojnike i vojna krivična dela što se, između ostaloga, vidi "i po tome što je za njeno izvršenje bilo potrebno mnogo ljudi (momaka), koji su se na jednom mestu u tolikom broju najlakše naći u vojsci". ${ }^{11}$ Ovu kaznu je izvršavao veliki broj ljudi čime je na neki način depersonalizovan izvršilac kako bi bile izbegnute velike neugodnosti koje je, u vojničkom kolektivu, mogao imati pojedinac (vojnik ili podoficir) koji je izvršavao telesnu kaznu.

Javno batinanje je, za osuđenog, predstavljalo neku vrstu građanske smrti, obzirom da je lice, nakon njenog izvršenja, bilo diskvalifikovano kako kao pravni tako i društveni subjekat. Sredina u kojoj je lice živelo ga je prezirala ili sažaljevala a bruka je pratila i njegovo potomstvo. Telesna kazna šibanja je imala za cilj odmazdu (ispaštanje) za izvršeno krivično delo kao i zastrašivanje kako osuđenog, tako i ostalih, kako se ubuduće povrede javnog poretka ne bi vršile. Sredstva za izvršenje telesne kazne zavisila su od pola i uzrasta lica kome je kazna izrečena. Za izvršenje kazne prema punoletnim muškarcima korišćeni su štap, prutevi (ili šibe), prema ženama kandžije a boj trskom ili rogozom za maloletnike. Telesna kazna šibanja ukinuta je u Srbiji 1859. godine a "inicijativu za njeno ukidanje dalo je Popečiteljstvo unutrašnjih dela". ${ }^{12}$ Telesna kazna šibanja ima dugu istori-

\footnotetext{
${ }^{6}$ Stojan Novaković, Ustavno pitanje i zakoni Karađorđeva vremena, (Beograd, Nova štamparija „Davidović,'1907), str. 5.

${ }^{7}$ Prota Mateja Nenadović, Memoari, (Beograd, Nolit, 1967), str. 79.

${ }^{8}$ Ibid.

${ }^{9}$ Punkt 4 glasi: „Ko uteče iz vojske bez dopuštenja, da trči šibu“, a punkt 5 glasi: „Sa straže koji pobegne, da se strelja“, citat prema: Nenadović, Memoari, str. 79.

${ }^{10}$ Momčilo Grubač, Telesna kazna u Srbiji (1804-1873), (Beograd, Službeni glasnik, 2004), str. 27.

${ }^{11}$ Ibid, str. 31.

${ }^{12}$ Grubač, Telesna kazna u Srbiji (1804-1873), str.33.
} 
Iskustva i pouke iz prošlosti

ju i kao takva primenjivana je i u vojskama najstarijih naroda. Tako su starešine misirske vojske "osobito često primenjivali batine, o čemu imamo puno dokaza iz raznih scena na njihovim spomenicima". ${ }^{13}$ Izricana je za različite greške kao što su greške pri razbroju vojnika, ispuštanje konja koji su spremani za vuču kola starešina i tsl.

Ova kazna često je primenjivana i u rimskoj vojsci (castigatio). Izvršavana je šibom koja je pravljena od lozovog korena (vitis) ,jer je batinanje štapom smatrano nečasnim”. ${ }^{4}$ Ovoj kazni podlegali su ne samo vojnici nego i oficiri tako da im čin u službi nije bio garancija da će izbeći ovu neugodnu kaznu. Pred kraj carstva ova kazna postaje znatno strožija i opasna po život iz razloga što je šiba od vinove loze zamenjena bičem od remenja na čijem kraju su se nalazili komadići olova. Jedino su veterani imali privilegiju da nisu mogli biti kažnjavani ovom kaznom.

Zakonikom Prote Mateje je za one, koji pobegnu sa straže bila propisana smrtna kazna. Smrtna kazna se, za vreme Prvog Srpskog ustanka, izvršavala na jedan od tri načina i to:

- najčešće vešanjem osuđenog krivca na kakvo drvo na mestu gde je učinio krivično delo. Niko nije smeo obešenog da skine sa drveta. Ovaj način je bio uobičajan u gotovo svim slučajevima što se da videti "u magistratskim presudama onoga vremena i u delovodnom protokolu Karađorđevom". ${ }^{15}$

- streljanjem osuđenog krivca pucanjem iz pušaka javno pred okupljenim narodom. Pre izvršenja kazne čitana je javna "sentencija" kako bi narod bio upoznat sa činjenicama kako je osuđeni zlo radio i šta je dočekao.

- proces izvršenja smrtne kazne nije se u pojedinim slučajevima okončavao smrću krivca nego je telo istoga, nakon izvršenja smrtne kazne stavljano "na točak gde je obično stajao dok se ne bi raspao". ${ }^{16}$

Mogućnost izvršenja smrtne kazne na više načina prisutna je u mnogim zemljama. U staroj rimskoj državi smrtna kazna nad vojnicima izvršavana na jedan od sledećih načina i to:

- odsecanjem glave mačem na častan način (decollatio);

- najpre udaranjem osuđenog jedanput štapom od strane tribunala nakon čega bi pristupili ostali vojnici i udarcima batinom i kamenovanjem osuđenog lišili života (fustuarium):

- smrtna kazna na izdajnicima i dezerterima izvršavana je na najokrutniji način (pribijanjem na krst, utapanjem, spaljivanjem, zakopavanjem živog u zemlju, izlaganjem divljim zverima u areni sl.), "jer se smatralo da su takve osobe izvršenjem dela izgubili i svoj vojni status i rimsko građanstvo, ukratko - da su postali neprijatelji a prema neprijateljima rimljani nisu poznavali obzira". ${ }^{17}$

Izvršenje smrtne kazne pratio je naročiti ceremonijal. Osuđeni je izvođen na posebna zadnja vrata logora (porta decumana) a čin izvršenja je najavljivan naročitim trubnim znakom velike trube (bucina) koja je, osim za izvršenje smrtne kazne korišćena za naja-

\footnotetext{
${ }^{13}$ Todor Lj. Pavlović, O vojnoj disciplini, (Beograd, "Dositej Obradović" - štamparija Ace M, Stanojevića, 1903), str 20.

${ }^{14}$ Bilten pravne službe, Krivična odgovornost vojnih lica u rimskom pravu, (Beograd, Vojna štamparija, 4/1963), str. 68.

${ }^{15}$ Toma Živanović, Zakonski izvori krivičnog prava Srbije i istorijski razvoj njegov i njenog krivičnog pravosuđa od 1804 do 1865, (Beograd, Naučno delo, Beograd, 1967, str. 433.

${ }^{16} \mathrm{lbid}$, str. 435.

${ }^{17}$ Bilten parvne službe, Krivična odgovornost vojnih lica u rimskom pravu, str. 68.
} 
vu imperatorovog ulaska u logor. Pred kraj Republike rimski vojnik je dobio pravo priziva na narodnu skupštinu u kom slučaju je o njegovom delu raspravljao sud u Rimu. Treba ipak uzeti u obzir činjenicu da položaj rimskog vojnika nije bio izuzetno težak jer je u vojsci postojala "gotovo neograničena mogućnost pomilovanja" ${ }^{18}$

U sačuvanim punktovima Zakonika Prote Mateje sadržane su odredbe o odgovornosti vojnika, čijim sagledavanjem se može konstatovati da su kazne rigorozne, određene po vrsti, ali ne i po visini, kada je u pitanju telesna kazna šibanja. Zakonik predstavlja izraz nastojanja da se uredi odgovornost vojnika u smislu decidnog propisivanja protivzakonitog ponašanja i rigoroznih kazni za njihovo činjenje. Ovaj Zakonik je poslužio kao uzor za donošenje kasnijih propisa.

\section{Karađorđev „Kriminalni zakonik“ iz 1807. godine}

Nakon Zakonika Prote Mateje iz 1804. godine, u Srbiji je 1807. godine donet Karađorđev „Kriminalni zakonik“, koji se označava kao drakonski krivični zakon „koji predviđa za to vreme aktuelna krivična dela i za ta dela određuje izuzetno stroge kazne“. ${ }^{19} \mathrm{U}$ pravnoj teoriji ne postoji jedinstven stav o vremenu nastanka ovog zakonika. Stojan Novaković smatra, da je nastao kasnije, i da isti treba „staviti u radnju sovjeta posle 1810 , gde se već u Srbiji bilo razvilo neko urednije stanje“. ${ }^{20}$ Nasuprot prethodnom mišljenju, Toma Živanović kao godinu izdanja označava 1807. godinu. Do navedenog podatka najverovatnije je došao prikupljajući građu za istoriju srpskog krivičnog prava, kojom prilikom je, u listu „Podunavka“, čitao tekst pod nazivom „Karađorđevi kriminalni zakoni“. List „Podunavka“ je izlazio kao prilog „Srpskih novina“, a navedeni tekst zakonika je objavljen u brojevima 3, 4 i 5, koji su štampani 1844. godine.

Od Karađorđevog kriminalnog zakonika, koji je imao 38 paragrafa, sačuvano je 25 . Sa aspekta vojno-kaznenih odredbi interesantni par. 14 (koji bi se vojnik usudio pri izgubljenju batalije za života oružje iz ruke dati ili baciti, bez izgovora da trči šibu mrtvu 6 puta kroz 600 momaka), ${ }^{21}$ par. 15 (koji bi se vojnik usudio u vojsci pušku budi našto izbaciti bez pitanja starešine i dopuštenja, 25 štapa da trpi), ${ }^{22}$ par. 21 (momci koji se na stražu odrede, i ako bi patrola zatekla šiljboka da je zaspao, šiljbok(u) šibe kroz 300 momaka 3 puta da trči, a kaplar njin, koji je među njima, po 50 štapa u dva jutra, a pročima po 25. Ako bi patrola zatajila i pro-

\footnotetext{
${ }^{18}$ Ibid, str. 69.

${ }^{19}$ Grubač, Telesna kazna u Srbiji (1804-1873), str. 33.

${ }^{20}$ Novaković, Ustavno pitanje i zakoni Karađorđeva vremena, str. 117.

${ }^{21}$ Kazna mrtve šibe se izvršavala tako što je osuđeni morao da trči šest puta dole i šest puta gore kroz stroj od 600 momaka koji su bili poređani u dva reda. Ova kazna je bila najteža telesna kazna koja je kod osuđenog, pored užasnih bolova za vreme izvršenja, za posledicu imala trajnu invalidnost i nesposobnost za rad. Ukoliko bi krivac, za vreme izvršenja kazne, pao stavljan je na kolica i vožen između redova momaka kako bi kazna bila izvršena. Izvršenje ove kazne često je za posledicu imalo smrt krivca.

${ }^{22}$ Telesna kazna boj štapovima izvršavala se na taj način što je osuđeni udaran štapovima po telu. Kako je štap tvrd to su bolovi od udaraca kao i moguće povrede unutrašnjih organa kod batinjanja, daleko veće nego u slučaju kada se za izvršenje telesne kazne upotrebljavaju druga sredstva. Stoga se osuđenom licu izricala kazna sa manjim brojem udaraca u odnosu na ostale telesne kazne. Ova telesna kazna se najduže održala u Srbiji i bila je u upotrebi do 1873. godine.
} 
Iskustva i pouke iz prošlosti

čulo se i osvedočilo, to isto patrola da trpi i oni), ${ }^{23}$ par. 22 (koji bi se starešina usudio ili kapetan ili kaplar, vojnike za mito iz vojske kući pustiti, ili za kakav dar svakom onom koji bio, propisuje se izdajničestvo, podleže sudu vojničkom koji da plati svakom svom vojniku koliko pod komandom njegovom stoji, po onoliko koliko je od onoga jednog uzeo, i u napred da se isključi iz vlasti) ${ }^{24}$ i par. 25 (svaki starešina svojoj vojsci da izda zapovest, u srbsku stoku ili kakvu rušadinu za život ne dirati, no gdi je baš nužda, da je vojska gladna, to kapetanu vojske da se prijavi, kapetan vojvodi, i po tom vojvoda da zaište od obližnji sela, neka pokupe i za novce donesu i u vojsci prodaju. A što bi sela na vojvodino iskanje dala, to vojvoda da popiše, koliko je primio da se račun može dati posle. Koj bi se vojnik usudio sam sobom učiniti i tuđe marvinče ubiti, taj da plati dvostruko i 25 štapa primi. A u koga bi se rušadina našla tuđa, taj šibu kroz 300 momaka (da trči) 3 puta zato što je svoga brata harao). ${ }^{25}$

Na osnovu citiranih paragrafa može se konstatovati da je ovaj zakonik karakterističan po sledećem:

- sadrži veći broj dela vojne prirode, jer se, od sačuvanih paragrafa, njih desetak odnose na vojna krivična dela i kazne predviđene za vojnike što je razumljivo kada se ima u vidu da je zakonik donet u periodu neprekidnih borbi;

- iz par. 22. je vidljivo da postoji „, vojnički sud“, koji je bio nadležan da raspravlja krivicu vojnih lica, a sve kazne su bile apsolutno određene po vrsti i po meri;

- par. 21. predviđa kolektivnu odgovornost svih momaka koji su određeni za stražu, ukoliko se „ma i jedan od njih, uhvati da na straži spava“26 što odudara od stava krivičnopravnih propisa 19. veka da je odgovornost individuvalna tj da kazna neposredno pogađa samo učinioca krivičnog dela. Osim ovoga treba istaći da se ovim paragrafom uvodi komandna odgovornost jer je bio kažnjavan i kaplar "iako na straži nije spavao, dakle po osnovu odgovornosti koju ima kao pretpostavljeni““. ${ }^{27}$

\section{Naredbe Karađorđa i Praviteljstvujuščeg sovjeta iz 1812. godine}

Osim zakonika, naredbama Georgija Petrovića Karađorđa i Praviteljstvujuščeg sovjeta kneževima su davana uputstva za upravljanje vojskom i narodom. Tako je u naredbi, koja je 1812. godine upućena Živku Šljiviću vojvodi u knežini Ramskoj, Požarevačke na-

\footnotetext{
${ }^{23}$ Kazna šibe se izvršavala tako što je šiljbok (stražar) do pojasa nag morao da trči kroz stroj momaka poređanih u dva reda tri puta u jednom i tri puta u drugom smeru. Svaki momak u stroju morao je osuđenog da udari po jednom prutom svaki put kada prođe pored njega. Kazna se izvršavala na javnom mestu u prisustvu naroda.

${ }^{24}$ Specifičnost ovoga paragrafa ogleda se u tome što je kazna starešini, kapetanu ili kaplaru, koji bi za mito ili dar pustio vojnika kući, propisana posredno pozivanjem na kaznu za drugo krivično delo (izdaju otadžbine). Osuđeni je bio lišen starešinske vlasti, morao je da isplati novčani iznos u visini mita svakom vojniku pod svojom komandom i napokon je kaštigovan (batinan) kao izdatelj otečestva tako što su mu prebijane obe ruke i obe noge na po dva mesta, dizan je na kolo sa koga nije skidan dok kost traje. Ovaj način izvršenja primenjivan je samo za najteža krivična dela kojima se u opasnost dovodila ideja oslobođenja.

${ }^{25}$ Funkcija telesne kazne koja je izricana vojniku koji ubije tuđe marvinče je da pojača dejstvo novčane kazne koja mu je za to izricana. Novčana kazna je u tom periodu je imala dva oblika i to globu i duplir. U konkretnom slučaju u pitanju je bio duplir jer je osuđeni plaćao kaznu u iznosu koji je dva puta veći od vrednosti ubijene životinje.

${ }^{26}$ Grubač, Telesna kazna u Srbiji (1804.-1873), str.57.

${ }^{27}$ Ibid.
} 
hije u tač. 6. propisano „za vojna prestupljenja dozvoljavamo vam kaštigovati krivca srazmerno prestupleniju i štapovima, a begunca iz vojske i onoga koji na poziv u vojsku ne dođe, možete kaštigovati šibom najdalje 300 momaka 3 puta. Prosti kapetan pak može, sa saglasijem vašim vojnog krivca kaštigovati sa 25 štapa, više ne“28, a u tač. 7 . je propisano „od kapetana vaših kojeg neposlušna ili nesposobna u službi nađete, dužni ste ga javiti nama i u sovet, s opisom krivice njegove. Na mesto takova predstavljaćete drugoga koga ćemo mi i sovet narodni, ako blagorasudimo, potvrditi““ ${ }^{29}$

Takve naredbe, koje su upućivane i drugim vojvodama i komandantima, odražavale su duh vremena, stanje ustaničkog prava i uređenja sudstva u srpskoj državi. Komandant i njegov kapetan su, u okviru svojih ovlašćenja, sudili srazmerno prestupleniju, ali je njihova nadležnost u pogledu izricanja visine telesne kazne bila ograničena. Kada je u pitanju krivica kapetana, komandant je bio obavezan da dokaze o njegovoj krivici dostavi u Praviteljstvujušči sovjet koji je, potom, o istoj odlučivao. Navedenim naredbama proširen je krug inkriminisanog ponašanja tako što su u njega uključena i ona koja se odnose na neodazivanje pozivu za vojsku, što je, počev od tada, inkriminacija prisutna u svim kasnije donetim propisima.

\section{Zakon voennij iz 1839. godine}

Nakon formiranja srpske stajaće vojske 31. oktobra 1839. godine donet je, Zakon voennij. ${ }^{30} \mathrm{U}$ ovom Zakonu nalaze se prve odredbe o disciplinskim kaznama, nadležnostima starešina za izricanje istih „pa stoga za ovaj Zakon možemo kazati da je osnovica za dalje razvijanje i stvaranje specijalnog zakona o vojničkoj disciplini i svih donetih uredaba o vojnoj disciplini u našoj vojsci“". ${ }^{31}$

Ovim zakonom je po prvi put propisano načelo koga se vojnici moraju pridržavati pri vršenju službe a koje glasi "zakone voene dužni su svi vojnici bez razlike dok su u službi, držati kako su zakletvu vojničku položili". ${ }^{32}$ Način vršenja vojne službe, u skladu sa zakonom, oficira, unteroficira, prostih vojnika bio je uređen sadržinom vojničke zakletve. ${ }^{33}$

\footnotetext{
${ }^{28}$ Milan Đ. Milićević, Kazne u Vojsci 1812, (Beograd, Srpska kraljevska štamparija, 1888), str.851.

${ }^{29}$ Ibid.

${ }^{30}$ Zakon voennij je imao 120 članova i bio podeljen prema sledećem: glava I (o zakletvi, par. 1-4), glava (o strahu božiem, par. 5-14), glava III (o činopočitaniu i pokornosti voennoj, par. 14-40), glava IV (o raznim vojničkim dužnostima, par. 40-49), glava V (o raani i plati, par. 49-54), glava VI (o odpustima iz službe, par. 54-57), glava VII (o pohodu, stroju i kordonu, par. 57-65), glava VIII (o garnizonu i logoru, par. 65-72), glava IX (o beguncima, par. 72-79), glava X (o izdai i buntu, par. 79-97), glava XI (o ubistvu, par. 97-102), glava XII (o bludu i nasilju, par. 102-106), glava XIII (o paležu, grabežu i krađi, par. 106-113) i glava XIV. (o opredeleniju kazne, par.113-120).

${ }^{31}$ Maleš J. Jakovljević, Praktičan komenetar Uredbe o vojnoj disciplini, (Beograd, Štamparija Ž. Madžarević, 1934), str. 8.

${ }^{32}$ Videti čl. 1. Zakona voennog iz 1839. godine.

${ }^{33}$ Videti čl. 4. Zakona voennog iz 1839. godine kojim je propisano "Ja (ime rekavši) zaklinjem se Bogom svemogućim, da ću služiti Otečestvu našem Serbiji čestno i verno; da ću njemu i njegovoj polzi istinno dušom i srcem predan biti; da ću ga čuvati i braniti od svakoga neprijatelja do poslednje kapi krvi; da ću Ustav zemljskij u svakom slučaju braniti i Knjazu Srpskom veran i poslušan biti; i zapovesti pretpostavljeni Načelnika i starešina slušati i točno ispunjavati, i da se njima nikada protiviti neću; da ću i dalju i noću, u boju, i na stražama kao voj-
} 
Iz sadržaja ovog zakona, može se izdvojiti nekoliko karakterističnih povreda discipline, kao što su one propisane u paragrafu $69,{ }^{34} 70^{35} \mathrm{i} 71^{36}$ Zakona voennog.

Kod većine kažnjivih radnji vrsta sankcije zavisila je od činjenice ko je izvršilac. ${ }^{37} \mathrm{Ka}-$ da se kao izvršilac javljao oficir, propisane kazne su bile: lišenje čina, arest (zatvor), a u najtežim slučajevima smrtna kazna, dok su kod vojnika vrlo česte „telesna kazna“ i „̌iba“. Kod mnogih dela, kazna nije određena, jer se za njihovo izvršenje propisuje „obično“ i „strogo kažnjavanje“ ili da će se učinilac „najstrožije kazniti“.

Odredbom par. 114 ovog Zakona propisane su kazne koje se mogu izreći učiniocu kao i nadležnost za njihovo izricanje.

Za manje krivice vojnika izriču se obične, lakše i nestroge kazne pod kojima se podrazumeva telesna kazna do 25 udaraca štapom po debelom mesu. Stupanjem na snagu Ustroenia sudova okružni 26. januara 1840. godine propisan je, u čl. 22. način izvršenja kazne boj štapovima. Za izricanje ove kazne nadležni su rotni ${ }^{38}$ komandiri i oni, pri izricanju, treba da se rukovode čistom savešću, zdravim razumom i prirodnom pravdom. Rotni komandir nije imao pravo da izrekne težu kaznu jer bi, u slučaju da to učini, to za posledicu moglo imati njegovo kažnjavanje, odnosno bio bi lišen zvanja. Pravo da lice stavi 24 sata u zatvor, ili da ga pritvori radi isleđivanja i neophodnog ispitivanja, nakon izvršenja kažnjive radnje, da ga veže i stavi pod stražu, imao je ne samo rotni komandir, već svaki starešina, bez obzira na čin.

Kada su u pitanju veće krivice, koje prevazilaze njegovu nadležnost, rotni komandir je slučaj predavao komandantu bataljona koji je mogao kaznu da udvoji do 50 štapova i da oficira stavi u zatvor na 24 sata.

Za veća zločinstva ${ }^{39}$ propisane su strože kazne pod kojima se podrazumeva kazna telesna od 25 do 50 udaraca ili zatvor, robija do 1 godine dana sa lakšim ili težim gvožđima i manja šiba.

nik hrabro se držati, i od sratmote vojsku našu i barjak ostaviti nikada neću; i da ću svagda zakonne vojenne tačno nabljudavati i dobrovoljno njima pokoravati se, i da se s neprijateljem Otečestva nikada slagati neću, i da ću se svagda ovako vladati, kako pravom, vernom i hrabrom Srpskom vojniku pristoi, kako da s čestju i pohvalom živim i slavno umrem - tako mi Gospod bog pomogao".

${ }^{34}$ Videti par. 69 Zakona voennog kojim je propisano „posle večernje molitve iz svog kvartira koe kuda tumarati i skitati se, da se ni jedan vojnik ne usudi. Koi bi se u to vreme izvan kvartira svog, osim slučaja službene dužnosti, ili osobite nužde, bez dopuštenja Načelnika svoga, našao, takovij će strogo kaznjen biti“.

${ }^{35}$ Videti par. 70 Zakona voennog kojim je propisano „svakij vojnik dužan e svoje oružie i amunične stvari, bilo u kasarni, bilo u kvartiru u vreme službe, bilo kod svoe kuće izvan službe, u čistom mestu držati i svagda čiste sodržavati. Nađe li se koi u tome nemarljiv, da bude kaznjen.".

${ }^{36}$ Videti par. 71 Zakona voennog kojim je propisano „u garnizonu, u logoru i na kordonu, dužni su svi vojnici čistotu nabljudavati, svagda i na svakom mestu. Koi bi se našao da nuždu svoju telesnu na mestu nepriličnom čini, vodu pijaću pogani i kvari, taj će strogo kaznjen biti“

${ }^{37} \mathrm{U}$ čl. 16 Zakona voennog (glava III - o činopočitaniju i pokornosti voennoj) bilo je propisano "koji bi se usudio svog Načelnika ili starešinu bezčestnim rečima ružiti i njegovoj čsti vred nanositi, taj, ako e oficir, lišiće se svoga čina, ako li e prostij vojnik, biće šibom kaznjen". Dakle za omalovažavanje pretpostavljenog oficir je bio kažnjavan gubitkom čina a običnom vojniku je izricana telesna kazna.

${ }^{38}$ Ustroeniem garnizonne vojske, koje je doneto 29. maja 1839. godine, Srbija je bila podeljena na 17 okruga, a u svakom okrugu je bila raspoređena rota pešadije koja je bila namenjena za čuvanje poretka i mira u zemlji. Rota je imala: jednog kapetana, jednog poručnika, jednog feldvebela, jednog kaptenarmusa (unteroficira koji u rotnoj kancelariji dužnost pisara vrši), 16 unteroficira, 4 dobošara, 2 signalista i 216 redova, svega 243 čoveka, četiri rote sačinjavale se jedan bataljon. Garnizona vojska sastoji se iz 4 bataljona i jedne rote, ova rota naziva se prvom i bila je pripojena prvom bataljonu koji je stacioniran u onom okrugu gde je Centralna uprava.

${ }^{39}$ Videti par. 115, Zakona voennog 
Za velika zločinstva ${ }^{40}$ određene su kazne koje su se sastojale u telesnoj kazni od 50 do 100 udaraca štapom, (kazna se izvršavala iz dva puta), teškoj tamnici i robiji sa gvožđem od 1 do 5 godina i velikom šibom.

Za najveća zločinstva ${ }^{41}$ određena je smrtna kazna koja se, u naročitim slučajevima, mogla zameniti smrtnom šibom.

Kazne za oficire, propisane su odredbama par. 118. Zakona, kao i nadležnost komandanta bataljona za njihovo izricanje. Pri izricanju istih, komandant treba da postupa pravedno, savesno i postepeno. Postepenost se ogleda u tome što je učiniocu izricana kazna u zavisnosti od težine učinjene greške, pa u slučaju da učinilac učini grešku teže prirode, i izrečena kazna je bila strožija.

Oficiru su, za učinjene pogreške, mogle biti izrečene sledeće kazne:

- za pogreške prvog nivoa oficiru je oduzimana sablja, a on je ostajao na slobodi,

- za pogreške drugog nivoa, oficiru je oduzimana sablja, stavljan je u zatvor ili podoficirsku stražu 24 sata,

- u slučaju da je načinio pogrešku trećeg nivoa, pored navedenih mera iz drugog nivoa, dodavan je i stražar na vratima zatvora gde je oficir kaznu izdržavao.

Rotni komandiri i komandanti bataljona su bili obavezni, da dostavljaju i predaju vojnom sudu svaki slučaj koji prevazilazi njihovu nadležnost. Vojni sud je, nakon isleđenja i ispitivanja okrivljenog, donosio presudu i izricao kaznu u skladu sa zakonom. U slučaju da je počinjeno veliko zločinstvo vojni sud je bio dužan "da podnese presude svoje pukovskom vojnom sudu, koji je kod glavnog štaba garnizone vojske kao najviše vojne vlasti i, ovaj će sud kao apelacioni vojni sud rečene presude pregledati i rešavati konačno i takve presude podnosiće se po čl. 3. "Nacionalnog ustava" na "usmotrenije knjazu"42 Organizacija i nadležnost vojnih sudova bila je propisana Ustrojenijem Garnizonog voinstva koje je doneto 10. januara 1845. godine prema kome je:

a) sud prvog stepena bio pri bataljonim kancelarijama i sastojao se "od jednog predsednika, tri člana i jednog pismenovoditelja" ${ }^{\prime 3}$. Funkciju predsednika suda vršio je bataljoni komandir, članova lica iz oberoficirskog reda a bataljoni ađutant dužnost pismenovoditelja. Ukoliko sud prvog stepena izrekne presudu koja nije veća od 50 štapova, ili zatvor i robiju od jedne godine, ili manju šibu (tri puta gore i tri puta dole kroz 300 momaka) ista se mogla "odmah u izvršenju dati" ${ }^{44}$ što znači da je žalba kažnjenog bila isključena. Ostale kazne koje prevazilaze ove koje izriče sud prvog stepena "moraće svagda pre izvršenja sudu drugog stepena na "razvidjenije" podnositi". 45

b) b) sud drugog stepena je bio pri glavnom vojnom štabu, takođe je sudio u kolegijalnom sastavu pri čemu su veće činili predsednik, četiri člana i jedan auditor. Funkciju predsednika vršio je načelnik štaba, a članovi su bili oberoficiri iz svih vojnih odeljenja i to pešačkog, topdžijskog i konjaničkog. Ovaj sud je, po službenoj dužnosti, vršio kontrolu

\footnotetext{
${ }^{40}$ Videti par. 116, Zakona voennog

${ }^{41}$ Videti par. 117, Zakona voennog

${ }^{42}$ Živanović, Zakonski izvori krivičnog prava Srbije i istorijski razvoj njegov i njenog krivičnog pravosuđa od 1804. do 1865, str. 135.

${ }^{43}$ Videti čl. 50 Ustroenija garnizonog voinstva.

${ }^{44}$ Videti čl. 52, Ustroenija garnizonog voinstva.

${ }^{45}$ Videti čl. 52, Ustroenija garnizonog voinstva.
} 
prvostepenih presuda, izricao konačnu presudu i davao je na izvršenje "osim u slučaju da je njome bila izrečena smrtna kazna, mrtva šiba ili lišenje oficirskog čina, kada je pre izvršenja preko Popečiteljstva unutrašnjih poslova dostavljana knjazu" ${ }^{\prime \prime 6}$. Navedene presude su dostavljene Knjazu na "usmotrenije" i pomilovanje.

Odredbe Zakona voennog, u delu koji se odnosio na disciplinsko kažnjavanje, primenjivali su se do 3. novembra 1862. godine kada je donet Zakon o vojničkoj disciplini.

Zakon voennij je unapredio sistem odgovornosti u vojsci propisujući opštu obavezu poštovanja Zakona za vreme službe, propisao pojavne oblike kršenja Zakona, i to kao manje krivice, veća zločinstva, velika zločinstva i najveća zločinstva, kao i nadležnost za izricanje sankcije koje se za njih izriču, a koje zavise od statusa lica, odnosno, da li je oficir, podoficir ili vojnik. Specifičnost ovog zakona predstavlja rešenje propisano u par. 12 kojim je bila propisana i mogućnost kažnjavanja lica koja nisu vršila vojnu službu. Naime, ukoliko se za vreme službe Božije u logoru vršila prodaja robe od strane krčmara ili drugih prodavaca (osim one koja je bila potrebna za bolesnog), oni su za navedeni prekršaj kažnjavani novčanom kaznom (globom) ukoliko su ga učinili prvi ili drugi put, a oduzimanjem robe u korist špitalja (bolnice) ukoliko su to učinili treći put. Nedostatak ovog Zakona se ogleda u činjenici da za pojedina protivpravna dela nije propisana kazna, već se upotrebljavaju termini „biće kažnjen“ ili „biće najstrože kažnjen", što je, najverovatnije, stvaralo problem u primeni i iniciralo izmene propisa u narednom periodu.

\section{Zakon o vojničkoj disciplini iz 1862. godine}

Zakon o vojničkoj disciplini donet je 1862. godine i predstavljao je izuzetan kvalitativni iskorak u odnosu na dotadašnje propise kojima je bila uređivana odgovornost vojnika. Naime njime se, po prvi put, kompleksno uređuje materija disciplinske odgovornosti kroz propisivanje radnji koje predstavljaju disciplinske istupe, načine njihovog izvršenja, kazne koje se mogu izreći izvršiocima, nadležnost za njihovo izricanje žalbe na izrečene kazne, i sl.

Nadležni starešina, pri kažnjavanju potčinjenih ima „svagda paziti na važnost krivice, pa prema tome blažiju ili strožiju kaznu izricati “47 i pri njenom izricanju, starešina treba da se „svake strasti, kao što su: zloba, zavist, osveta, mrzost, it.p. pa i same lične naklonosti najbrižljivie kloni“" ${ }^{4}$

Pojavni oblici disciplinskih istupa propisani su u par. 6 i oni se, unekoliko razlikuju kada su u pitanju starešine, odnosno vojnici. ${ }^{49}$

\footnotetext{
${ }^{46}$ Grubač, Telesna kazna u Srbiji (1804-1873), str.86.

${ }^{47}$ Videti par. 7 st. 1 Zakona o vojničkoj disciplini.

${ }^{48}$ Videti par. 9, Zakona o vojničkoj disciplini.

${ }^{49}$ Videti par. 6, Zakona o vojničkoj disciplini kojim je propisano da starešina čini disciplinarna istupljenja kada govori: nepristojne psovke i ruženja, bezčestne reči, nečovečno postupa s mlađim i nepravedno kaznenj, a vojnik čini disciplinarna istupljenja kada: gunđa, nepristojne i sramotne reči govori, kada je neposlušan, nemarljiv i neuredan u dužnostima, kada se ne povinuje pravilima i naredbama, kada izjavljuje i propoveda takva načela koja su protivna redu i koja se ne slažu sa službenim dužnostima, kada se nemoralno vlada (opija se, narušava vojnički ili građanski red,skita se, javno se karta, svađa bilo sa vojnicima ili građanima, zadužuje se, kada ne
} 


\section{Disciplinske kazne za oficire i način njihovog izvršenja}

Oficirima se, shodno par. 15, za pogreške u disciplini, mogu izreći sledeće kazne i to: ukor, domaći prosti i strogi pritvor, zatvor i udaljenje od zvanja do 6 meseci.

Pretpostavljeni starešina, kaznu ukora je izricao na način propisan u par. 16 Zakona. ${ }^{50}$

Domaći prosti pritvor oficiru je mogao izreći oficir višeg čina od njegovog, kao i oficir istog čina ukoliko je od njega stariji i ako mu je komandir. Pravo izricanja i način izvršenja ove kazne bili su uređeni par. 17 Zakona. ${ }^{51}$ Visina kazne prostog domaćeg pritvora, koja se mogla izreći oficiru, propisana je par. $18^{52}$ Ovaj pritvor je prestajao "u vreme koe e naznačeno, bez ikakve formalnosti”. ${ }^{33}$ Strogi domaći pritvor oficiru je mogao izreći ministar vojni, načelnik artiljerijske uprave, načelnik štaba, garnizoner (komandant garnizona) i častni komandir. Način izvršenja ove kazne unekoliko se razlikovao od prethodne i bio je propisan u par. 19 st. 2 Zakona. ${ }^{54}$ Visina kazne strogog domaćeg pritvora, zavisila je od čina i položaja lica $^{55}$ koje je kaznu izricalo. Kazna pritvora mogla se izreći usmeno ili pismeno. Kada se izricala pismeno oficiru, akt o izricanju kazne mu je dostavljan, u zapečaćenom pismu.

Kaznu zatvora ${ }^{56}$ oficiru je mogao izreći načelnik štaba i načelnik artiljerijske uprave u trajanju do osam, a ministar u trajanju do 15 dana.

Udaljenje od zvanja do šest meseci, oficiru je, na predlog ministra vojnog, izricao knjaz. Razlozi za udaljenje bili su propisani u par. 31 Zakona. ${ }^{57}$ Oficir za vreme, dok je

odlazi na prozivke ili inače na službu, kada postupa suprotno zapovestima i građansko - policajnim naredbama i čini sve ono što je protivno vojničkim dužnostima i što je nedostojno jednog vojnika).

${ }^{50}$ Zakonom o vojničkoj disciplini u par. 16 bilo je propisano da se kazna ukora oficiru izriče u prisustvu jednog ili više oficira koji imaju viši čin od njegovog ili pred oficirima istog čina kojima je starešina koji je izrekao kaznu naredio da prisustvuju njenom izricanju.

${ }^{51}$ Zakonom o vojničkoj disciplini, u par. 17 je bilo propisano da svakom oficiru može odrediti prosti domaći pritvor oficir višeg čina od njegovog, pa i istog čina, ukoliko je od njega stariji i komandir mu je. Za vreme izdržavanja kazne oficir nije razrešen od dužnosti i mora, za vreme kada nije na službi, biti kod svoje kuće i mogao je primati samo lice koje dolazi u službenu posetu. Ako bi oficir učinio kakvu pogrešku u pritvoru isti mu se produžavao.

${ }^{52}$ Zakonom o vojničkoj disciplini, u par. 18 je propisano: „poručnik može odrediti prostog domaćeg pritvora najviše 2 dana, kapetan 8 dana, časnij komandir 12 dana, načelnik glavnog štaba i artiljerijske Uprave 20, a minister 30 dana".

${ }^{53}$ Videti par. 24 st. 1, Zakona o vojničkoj disciplini.

${ }^{54}$ Pri izdržavanju navedene kazne oficir nije vršio dužnost, morao je sve vreme boraviti u kući i nije imao pravo na posetu. Sablju svoju, po dežurnom naredniku, slao je onom ko mu je kaznu izrekao. Za vreme izdržavanja kazne, primao je polovinu plate.

${ }^{55}$ Zakonom o vojničkoj disciplini, u par. 19, propisano je „častnij komandir može odrediti strogog domaćeg pritvora do 4 dana, garnizoner 7, načalnik štaba i načalnik Artiljerijske uprave 10, a minister 20 dana“.

${ }^{56}$ Zakonom o vojničkoj disciplini, u par. 20 st. 2 bilo je propisano da je kaznu zatvora oficir izdržavao u za to određenoj sobi u kasarni, a pre odlaska na izdržavanje kazne predavalo je sablju licu koje mu je kaznu izreklo. Izdržavanje kazne je bilo uređeno posebnim propisima o čijem izvršenju se starao glavni dežurni, a u par. 21 da mu za vreme izdržavanja kazne zatvora ili strogog domaćeg pritvora pripada polovina plate.

${ }^{57}$ Zakonom o vojničkoj disciplini, u par. 31 je propisano da se kazna udaljenja od zvanja na neko vreme izriče oficiru ako se nemoralno vladao, zaduživao zbog raskošnog života, davao izjave i propagirao takva načela kojima se red kvari i koja su suprotna službenim dužnostima, a naročito pozivu jednog vojnika i uopšte pri svim istupima koji se odnose na ponižavanje vojničkog reda, kao i u slučaju kada je oficir već dva ili više puta bio disciplinski kažnjavan. 
Iskustva i pouke iz prošlosti

udaljen od zvanja, nije vršio nikakvu službu i primao je $2 / 3$ svoje plate. Za vreme udaljenja od dužnosti morao se ponašati na način kao da se nalazi u aktivnoj službi, a "učinili protivno, podležaće onako isto odgovoru kao kad bi na dužnosti bio" ${ }^{58}$

Oficir koji bi u toku godine više puta bio kažnjen blažim administrativnim kaznama (ukor, prost ili strogi domaći pritvor) ili dva puta strožim disciplinarnim kaznama (zatvor ili udaljenje od zvanja), a učinio bi, u navedenom vremenu još neko disciplinarno istupljenje, mogao je, radi lišenja zvanja, biti predat sudu.

\section{Disciplinske kazne za niže činove i način njihovog izvršenja}

Nižim činovima (narednicima i podnarednicima), su se, shodno paragrafu 36 mogle izreći sledeće kazne: pritvor, prosti zatvor, strogi zatvor i lišenje čina. Narednicima i podnarednicima se kazna pritvora izricala za neuredno držanje uniforme, kako njihove tako i vojnika koji su im potčinjeni.

Prosti zatvor se izricao za pogreške u disciplini koje su učinjene u kasarni. Za vreme izdržavanja kazne prostog zatvora podoficir ne ide na dužnost „osim što zajedno sa ostalima mora biti na časovima učenja“. ${ }^{59}$ Strogim zatvorom kažnjavaju se podoficiri za važnije pogreške, između kojih i za one "koje se učine za vreme službe pod oružjem". ${ }^{60}$ Za vreme izdržavanja kazne strogog zatvora podoficir nije vršio nikakvu dužnost a primao je polovinu plate.

Pritvor i prosti zatvor ne mogu se izreći u trajanju dužem od 15 dana, a strogi zatvor $u$ trajanju dužem od 8 dana. Nadležnost za izricanje kazne pritvora, prostog zatvora i strogog zatvora kao i maksimalno trajanje istih propisana je odredbama paragrafa 38 Zakona. ${ }^{61}$

\section{Disciplinske kazne za obične vojnike i način njihovog izvršenja}

Prostim vojnicima mogu se izreći sledeće kazne: pritvor, prosti i strogi zatvor i boj. Kazna pritvora se može izreći u trajanju do 30 dana i njom „se vojniku zabrani za neko vreme izlaziti iz kasarske ograde“. ${ }^{62}$ Za vreme izdržavanja kazne je vršio svoju vojničku dužnost.

Vojnicima, koji su kažnjeni prostim zatvorom, ova kazna se mogla izreći u trajanju do 20 dana i za vreme izdržavanja iste vojnici su obavljali svakodnevnu službu, a mogli su biti angažovani i na radovima koji su se izvodili u kasarni.

Kazna strogog zatvora se izricala u trajanju do 15 dana, a vojnik za vreme izdržavanja iste nije vršio službu i nije primao platu.

\footnotetext{
${ }^{58}$ Videti par. 34, Zakona o vojničkoj disciplini.

${ }^{59}$ Videti par. 39, Zakona o vojničkoj disciplini.

${ }^{60}$ Videti par. 37, Zakona o vojničkoj disciplini.

${ }^{61}$ Zakonom o vojničkoj disciplini, u par 38, propisano je: „Narednik može odrediti uopšte 2 dana pritvora ili 1 dan prostog zatvora. Narednik pak u svojoj roti (bateriji, eskadronu) može odrediti 4 dana pritvora, ili 2 dana prostog zatvora. Potporučnik i poručnik mogu odrediti 6 dana pritvora ili 3 dana prostog zatvora, ili 1 dan strogog zatvora. Kapetan ima vlast odrediti 8 dana pritvora, ili 4 dana prostog zatvora, ili 2 dana strogog zatvora. Kapetan pak u svojoj roti (bateriji, eskadronu) može odrediti 15 dana pritvora, ili 8 dana prostog zatvora., ili 4 dana strogo zatvora. Častni komandir može odrediti 15 dana prostog zatvora, ili 8 dana strogo zatvora“.

${ }^{62}$ Videti par. 40 st. 2, Zakona o vojničkoj disciplini.
} 
Nadležnost za izricanje kazne pritvora, prostog i strogog zatvora, prostim vojnicima kao i trajanje istih zavisila je od čina i položaja lica koje kaznu izriče i bila je uređena par. 43 Zakona. ${ }^{63}$

Nadležnost za izricanje kazne boja pripadala je isključivo oficirima, i to počev od kapetana u roti (bateriji, eskadronu) koji je mogao izreći kaznu boja do 20 udaraca, časni komandir do 25 a najviše starešine do 30 udaraca. ${ }^{64}$

Osim napred navedenih kazni, zakonom je, u par. 49-55, bila predviđena mogućnost da vojnici nižeg čina, narednici, pisari i podnarednici mogu biti lišeni svog čina za neko vreme koje ne može trajati duže od dva meseca. Kada je u pitanju kazna lišenja čina, ista je imala dva pojavna oblika, i to u slučaju kada vojnik bude osuđen na oduzimanje jednog čina ili oduzimanje čina uopšte i vraćanje u redove vojnika.

Vojnik kažnjen oduzimanjem jednog čina "dužan e vršiti službu onoga čina, koi e odma ispod toga", 65 odnosno obavlja dužnost onog čina koji je, po vojnoj hijerarhiji, neposredno ispod onog koji mu je oduzet. Kada se naredniku ili podnaredniku oduzima čin uopšte tada se on statusno vraća u redove vojnika, premešta u drugu rotu (bateriju, eskadron) i, samim tim, ubuduće obavlja vojničke dužnosti.

Ova kazna se „ima upotrebiti za vrlo znatne pogreške ili kad se već dokaže da se okrivljenij nikako popraviti nemože" ${ }^{66}$ a sa izrečenom kaznom se upoznaju sva lica kroz saopštavanje dnevne naredbe.

Protiv izrečene kazne lice se moglo žaliti. Žalba se mogla uložiti ukoliko je, "na osnovu neistiniti i netočni izvestia nepravedna, ili vrlo stroga kazn izrečena, ili su takva pobuđenja za osnov izricanja kazni uzeta, koja se na službu nikako neodnose". ${ }^{67}$ Ista se mogla izjaviti isključivo lično, nakon izdržane kazne, a ukoliko je lice, pri njenom izjavljivanju bilo u stanju pijanstva žalba lica se nije saslušavala. Vojnici i pododficiri su žalbu mogli podneti oficiru, odnosno svom kapetanu, a oficiri svom častnom komandiru. Oficiri su bili obavezni „žalbe ladnokrvno saslušavati, brižljivo im istinu istraživati, i ako su pravedne udovletvoravati im", 68 a ukoliko je žalba neosnovana i neistinita žalilac je u tom slučaju bio kažnjavan. Običan vojnik se mogao žaliti načelniku štaba ako je bio kod časnog komandira koji mu nije žalbu uvažio ili se žalio na samog častnog komandira.

\footnotetext{
${ }^{63}$ Zakonom o vojničkoj disciplini u par. 43, propisano je: „Mlađi podnarednik može odrediti 6 dana pritvora ili 2 dana prostog zatvora. Stariji podnarednik, pisar i narednik 8 dana pritvora ili 4 dana prostog zatvora. Narednik u svojoj roti (bateriji, eskadronu) 10 dana pritvora ili 5 dana prostog zatvora. Potporučnik i poručnik 15 dana pritvora ili 8 dana prostog zatvora, ili 2 dana strogog zatvora. Kapetan 20 dana pritvora, ili 10 dana prostog zatvora, ili 4 dana strogog zatvora. Kapetan u svojoj roti (bateriji, eskadronu) 30 dana pritvora, ili 20 dana prostog zatvora, ili 10 dana strogog zatvora ili boj do 20 udaraca. Castni komandir 15 dana strogo zatvora, ili boj do 25 udaraca, veći starešina, može narediti do 30 udaraca“.

${ }^{64}$ Zakonom o vojničkoj disciplini, u par. 42 st. 2, propisano je da se ovom kaznom kažnjavao onaj prost vojnik „koi e više puta grešio i zbog razni, ili podobnog roda krivica na sve druge kao blažieg roda kazni osuđivan bio, pa su iste bez ikakvog uspeha ostale i tako se kao nepopravim pokazue, ili koi e kakvo veće disciplinarno istupljenj učinio, da se prema veličini istuplenja svaka druga disciplinarna kazn kao blaga pokazue“.

${ }^{65}$ Videti par. 49, Zakona o vojničkoj disciplini.

${ }^{66}$ Videti par. 53, Zakona o vojničkoj disciplini.

${ }^{67}$ Videti par. 57, Zakona o vojničkoj disciplini.

${ }^{68}$ Videti par. 60, Zakona o vojničkoj disciplini.
} 
Zakon o vojničkoj disciplini je postavio temelje za donošenje budućih propisa kojima će se uređivati disciplinska odgovornost. Predvideo je, u paragrafu $11^{69}$ odgovornost za povrede javnog reda koje učine vojnici, propisao opšte osnove počinjenosti, istupljenja i kazne koje se izriču pojedinim kategorijama lica, predvideo žalbu kao pravni lek koju kažnjeni može koristiti. Donet je godinu dana posle Zakona o činovnicima građanskog reda koji je propisao održavanje reda i dostojanstva u službi i među činovnicima, a za narušavanje istih propisao kazne pismeni ukor i oduzimanje plate za tri meseca. Srbija je nastojala da putem zakona uredi odgovornost onih kojima je poslodavac, i u ovom slučaju, Zakon o vojničkoj disciplini je to sveobuhvatnije učinio. Dopunjen je Uredbom o disciplinarnom kaznenju u narodnoj vojsci koja je doneta 22. septembra 1872. godine.

\section{Zaključak}

Odgovornost ima izuzetan značaj u procesu stvaranja kako države tako i vojske kao organizovane oružane sile koja prati ljudsko društvo kroz sve periode njegovog razvoja. Kako je vojska organizacija koja ima specifičnu odgovornost u društvu koja se ogleda u zaštiti vojne bezbednosti to njeni pripadnici imaju dužnost da izvrše sve zadatke i obaveze koji su im dati u službi. Propuštanje izvršavanja pojedinih dužnosti, nesavesno postupanje, neizvršavanje naređenja i slično, mogu, kako u mirnodopskim uslovima tako i u ratnim, rad i funkcionisanje vojske dovesti u tešku situaciju. Stoga je odgovornost poželjan kvalitet pripadnika vojske. Kako u pojedinim situacijama može doći do narušavanja odgovornosti od strane pripadnika vojske to se javila potreba normativnog uređenja pravnih oblika odgovornosti kojima društvo ukazuje na devijantna ponašanja koja odstupaju od utvrđenog standarda ponašanja. Propisi nastali u navedenom vremenu kao i oni doneti nakon toga nam ukazuju na činjenicu da stvaranje idealnog sistema odgovornosti nije okončan postupak ni u sadašnjem vremenu. Sistem odgovornosti manifestuje probleme u pojedinim segmentima što je odraz nepotpunog sagledavanja pojedinih pitanja kao i propisivanja neadekvatnih rešenja koja nisu odgovarajući put za rešavanje problema.

\section{Literatura}

[1] Grubač, Momčilo, Telesna kazna u Srbiji (1804-1873), (Beograd, Nolit, 1967).

[2] Živanović, Toma, Zakonski izvori krivičnog prava Srbije i istorijski razvoj njegov i njenog krivičnog pravosuđa 1804-1865, (Beograd, Naučno delo, 1967).

[3] Živanović, Toma, Osnovi vojnog krivičnog prava (opšti deo), (Beograd, Grafički Institut „Narodna misao“, 1924).

[4] Jakovljević, Maleš J, Praktičan komentar uredbe o vojnoj disciplini, (Beograd, Štamparija Ž. Madžarević, 1934).

\footnotetext{
${ }^{69}$ Zakonom o vojničkoj disciplini, u par. 11 propisana je odgovornost za povrede javnog reda, tako što se tiče službe i javnog reda, svakij vojnik može biti kaznjen vojnikom, koi e ma i edan čin stari od njega, pa bio on kog mu drago odelenja ili roda oružja.
} 
[5] Milićević, Milovan $Đ$, Kazne u vojsci 1812, (Beograd, Srpska kraljevska štamparija, 1888).

[6] Nenadović, Prota Mateja, Memoari, (Beograd, Nolit, 1967).

[7] Novaković, Stojan, Stara srpska vojska, (Beograd, Kraljevsko-srpska državna štamparija, 1898).

[8] Novaković, Stojan, Ustavno pitanje i zakoni Karađorđeva vremena, (Beograd, Nova štamparija „Davidović", 1907).

[9] Pavlović, Todor Lj, O vojnoj disciplini, (Beograd, „Dositej Obradović“ - štamparija Ace M. Stanojevića, 1903).

[10] Radojičić, Nikola, Zakonik Cara Stefana Dušana 1349. i 1354, (Beograd, Naučno delo, 1960).

[11] Solovjev, Aleksandar V, Zakonik Cara Stefana Dušana 1349. i 1354. godine, (Beograd, SANU, 1980).

[12] Bilten pravne službe, Krivična odgovornost vojnih lica u rimskom pravu, (Beograd, Vojna štamparija, 4/1963).

[13] Zakon voennij 1839.

[14] Zakon o vojničkoj disciplini 1862.

[15] Ustroenie garnizonne vojske 1839. 